\title{
A NEW MASDEVALLIA (ORCHIDACEAE: PLEUROTHALLIDINAE) FROM A DEFORESTED AREA IN THE HUANUCO REGION OF PERU
}

\author{
Stig DAlströM ${ }^{1,3} \&$ SAUl Ruíz PÉREZ ${ }^{2}$ \\ ${ }^{1} 2304$ Ringling Boulevard, unit 119, Sarasota FL 34237, U.S.A.; Lankester Botanical Garden, \\ University of Costa Rica; The National Biodiversity Centre, Serbithang, Bhutan \\ ${ }^{2}$ Allamanda 142, Surco, Lima 33, Peru \\ ${ }^{3}$ Author for correspondence: stigdalstrom@gmail.com
}

\begin{abstract}
A new and showy species of Masdevallia from the Huanuco region in Peru is described and illustrated with a line drawing and color photographs. It belongs to the subgenus Masdevallia, section Masdevallia. The new species is compared to several more or less morphologically similar species, such as $M$. burianii, M. cranion and M. popowiana that appear to be closely related. The new species differs from them by a combination of features, including the rather fleshy leaves and the bell-shaped flowers covered internally with magenta to white pubescence.
\end{abstract}

Key words: Huanuco, Masdevallia, new species, Peru, Pleurothallidinae

Introduction. The genus Masdevallia Ruíz \& Pav. is one of the more well-known and popular orchid genera in cultivation. It has therefore also been of interest to many taxonomists over the years. Several groups of species that were originally described as Masdevallia have been separated since the genus was established and generally been accepted as genera of their own, such as Dracula Luer, Porroglossum Schltr., Scaphosepalum Pfitzer and Trisetella Luer. Despite these and other transfers from Masdevallia, the genus is still large today with over 600 species, classified into numerous subdivisions (Luer 1986, 2000a,b, 2001, 2002, 2003). This vast number of species, in combination with molecular investigations (Pridgeon \& Chase 2001, Abele et al. 2005), eventually encouraged Luer to split the genus into 16 new genera, in addition to the remaining Masdevallia (Luer 2006). This latter treatment has not been generally accepted (Dalström \& Ruíz Pérez 2014) so the genus is more generally accepted in a broader sense, basically as it was earlier circumscribed by Luer.

\section{TAXONOMIC TREATMENT}

Masdevallia tatianae Dalström \& Ruíz-Pérez, sp. nov.

TYPE: Peru. Huanuco. Along and above the road between Uchiza and Huacrachuco, in a patch of dense and scrubby cloud forest west of San Pedro de Chonta, alt. ca. $2500 \mathrm{~m}$, collected by S. Ruíz on 1 Dec. 2013, and flowered in cultivation by Perúflora, Nov. 2015 (Masdevallia sp. 401020) S. Dalström 3785 (holotype: USM). Figs. 1-4.

Masdevallia tatianae belongs to the subgenus Masdevallia, section Masdevallia, and appears most similar to M. burianii Luer \& Dalström, M. cranion Luer and M. popowiana Königer, but differs from $M$. burianii in having much sturdier and thicker leaves, petals with a truncate apex versus a rather narrow and oblique acute apex for the petals of $M$. burianii, a lip with a distinctly narrowed apical part versus an almost truncate apex for the lip of M. burianii, and M. tatianae differs from M. cranion in the erect inflorescence versus a subhorizontal and $c a$. half as long inflorescence, by a lip with a distinctly narrowed apical part versus an evenly ovate lip lamina for $M$. cranion, and densely pubescent inner surfaces of the sepals versus cellular-papillose inner surfaces of the sepals for M. cranion, and M. tatianae differs from M. popowiana by the pubescent inner surfaces of the sepals versus basically glabrous inner surfaces of the sepals, and by the rounded cupulate flowers versus flowers with a distinct ventral mentum formed by the lateral sepals in M. popowiana.

Epiphytic herb. Plant medium sized for the subgenus, caespitose. Ramicauls erect, rather thick, ca. $2.8-3.2 \mathrm{~cm}$ long, enclosed basally by 3 tubular sheaths. Leaf erect, coriaceous, petiolate, blade basally 


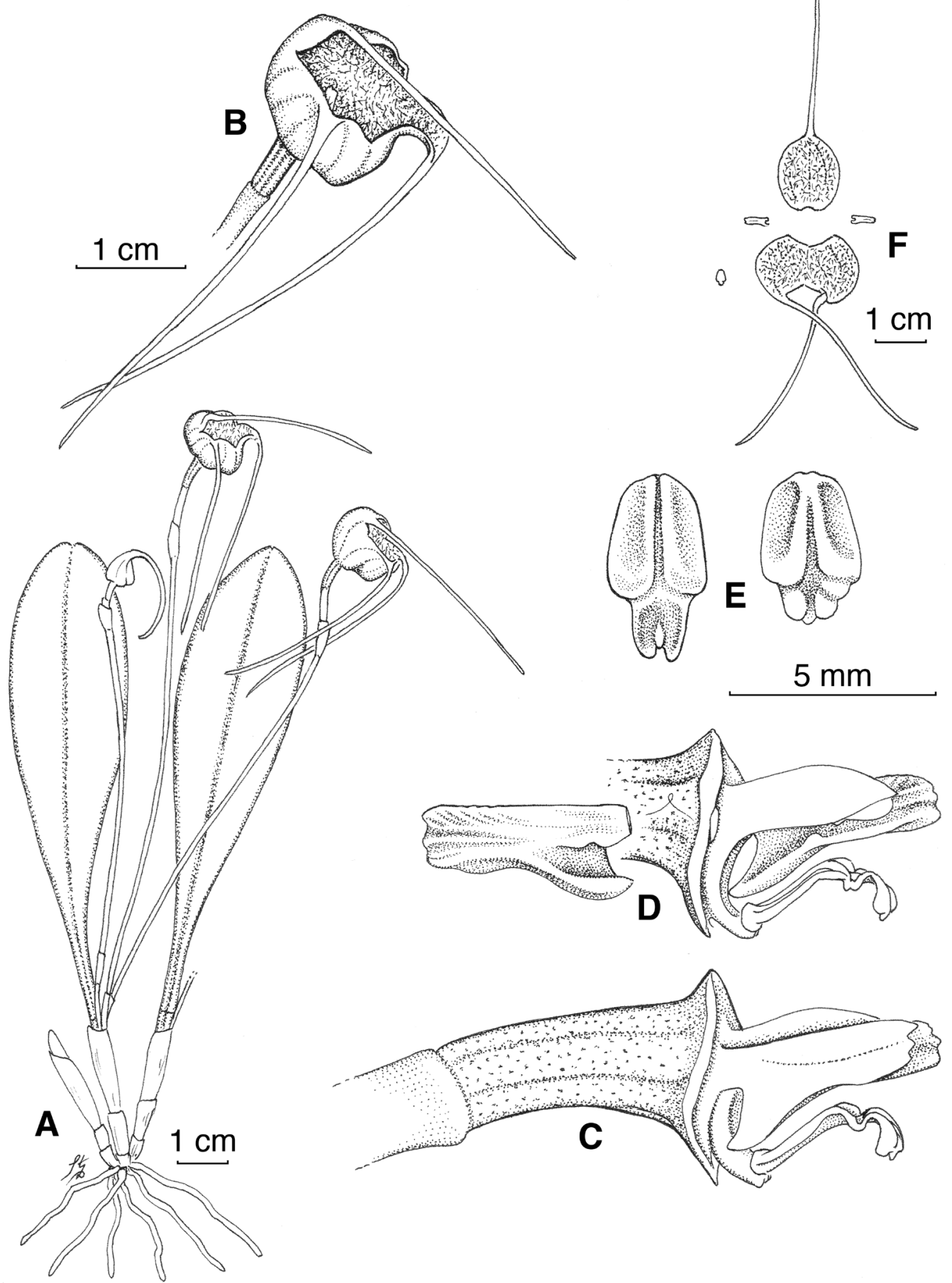

IGURE 1. Masdevallia tatianae Dalström \& Ruíz-Pérez. A. Plant habit. B. Flower. C. Ovary, lip and column, including the petal, lateral view. D. Ovary, lip and column, with removed and flipped petal, lateral view. E. lip normal and flattened dorsal views. F. Dissected flower. Drawn from holotype by Stig Dalström. 
conduplicate and cuneate, ovate to elliptic, obtuse, to $c a .10 .0 \times 2.5 \mathrm{~cm}$, including the $c a .2 \mathrm{~cm}$ long petiole. Inflorescence erect, terete, single flowered, with an up to $c a .10 \mathrm{~cm}$ long peduncle; peduncular bract 1, tubular, near the base of the peduncle, $c a .6$ $\mathrm{mm}$ long; floral bract appressed, tubular, ca. $7 \mathrm{~mm}$ long; pedicel excluding the ovary to $c a .15 \mathrm{~mm}$ long; ovary shallowly sulcate, smooth, with scattered tiny "fungal pits" (tiny pits where it is speculated here, but not proven, that some fungi establish, based on visual observation only), ca. 4-5 mm long. Flower deeply cupulate, forming a $c a$. $10 \mathrm{~mm}$ long sepaline cup; dorsal sepal pale yellow with basal magenta spots and the apical tail gradually turning purplish, connate to the lateral sepals for $c a$. 5-6 $\mathrm{mm}$, then obtuse, internally covered by magenta to whitish hairs, $c a .15$ $\times 12 \mathrm{~mm}$, with a slender apical, more or less forward to downward pointing, basally yellowish turning gradually purplish $c a$. $38-40 \mathrm{~mm}$ long tail; lateral sepals similar in texture and coloration, connate for $c a$. $8 \mathrm{~mm}$, then obliquely ovate and obtuse, $c a .12-13 \times$ $10-11 \mathrm{~mm}$, with apical, slender, yellowish and purplish ca. 38-40 mm long tails; petals translucent, glass-like and colorless, cartilaginous, unguiculate with a distinct lateral, triangular and involute fleshy lobe, extending from the base to the middle of the length, then rather linear with a truncate and indistinctly tridentate apex, ca. $5.0 \times 1.5 \mathrm{~mm}$; lip basally pale yellow, then with pale purple hue and specks, the apical part brownish to purplish with a dark purple apicule, hinged on the hook-shaped column foot by a minute strap-like tissue, basally broadly ovate with a minor longitudinal furrow, then distinctly angled into a narrower epichile that is linear when flattened and apically bilobed with a small fleshy rounded knob in between. ca. $4.5 \times 2.5$ $\mathrm{mm}$ when flattened; column pale yellow with magenta lower edges, straight, $c a .4 \mathrm{~mm}$ long, with an equally long, curved and apically hook-shaped foot; anther cap pale yellow and campanulate; pollinia not seen.

Paratype: Peru. A small population of plants without flowers was observed in the same location as the holotype. No other collections known.

Distribution: Masdevallia tatianae is only known from the type locality.

Eponymy: This species is named in honor of Tatiana

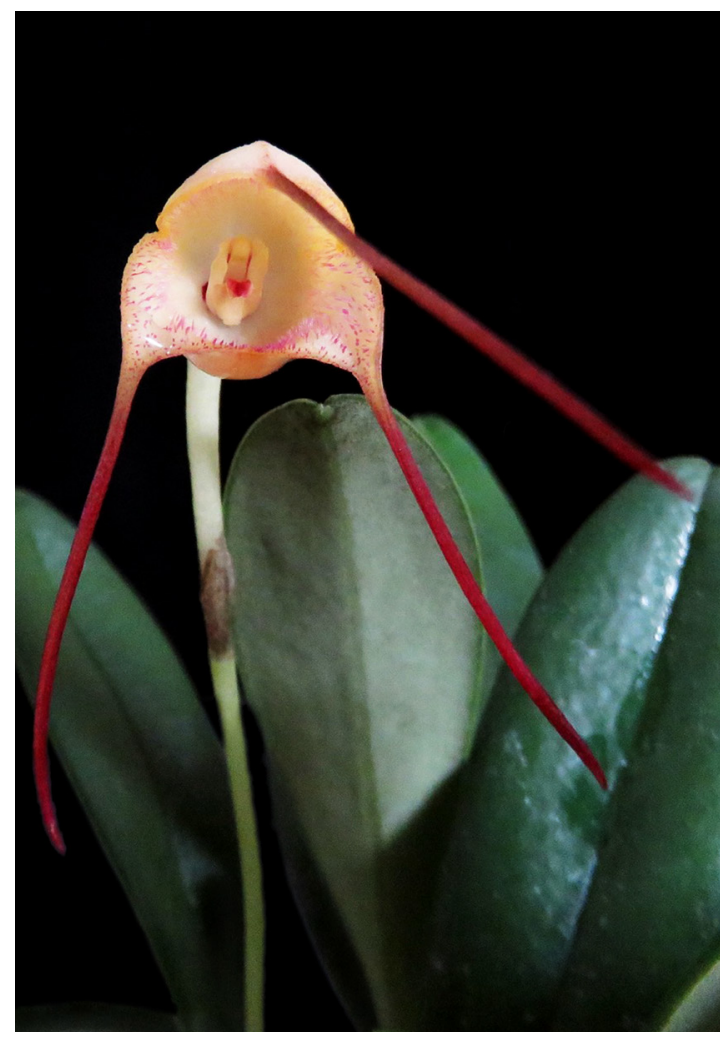

Figure 2. Masdevallia tatianae. Front view of the flower. Flowered in cultivation and photographed by Perúflora.

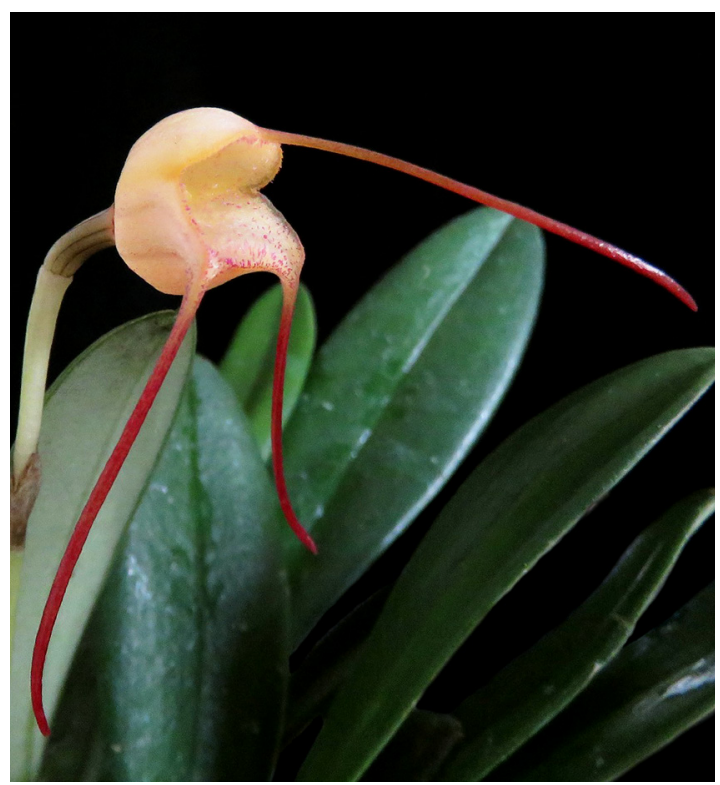

FIgure 3. Masdevallia tatianae. Three quarters view of the flower. Flowered in cultivation and photographed by Perúflora. 


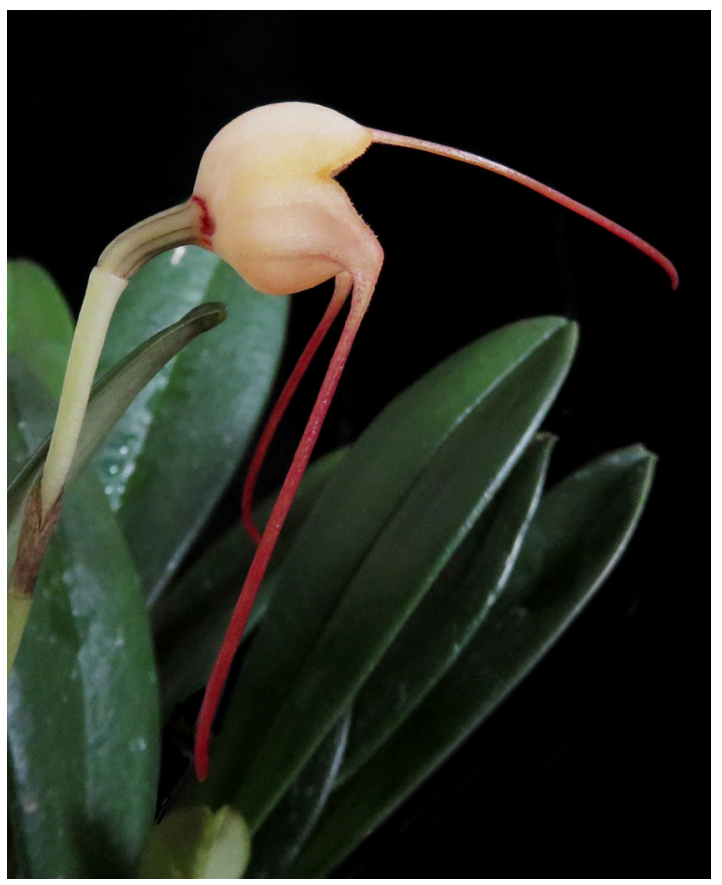

Figure 4. Masdevallia tatianae. Lateral view of the flower. Flowered in cultivation and photographed by Perúflora.
Leyla Ruíz Sanchez, the daughter of the discoverer and second author, on his request.

Masdevallia tatianae was originally discovered by Saúl Ruíz and his brother Moises during a field trip in October 2013. A few plants were growing epiphytically in a small patch of remaining scrubby cloud forest in an otherwise heavily deforested area (Fig. 5). Very little remains of the original forest in that entire region and many plant species are without a doubt doomed to disappear in a near future. Masdevallia tatianae appears to be most closely related to species such as M. burianii, M. cranion and M. popowiana, due to the rounded and bell-shaped flower. But the rich internal pubescence also reminds of features displayed by members of the subsection Saltatrices.

ACKNOWLEDGMENTS. We thank the staff at the Instituto Recursos Naturales (INRENA), and Betty Millán and Ricardo Fernández at the Universidad de San Marcos, Museo de Historia Natural, Lima. We also thank Wesley Higgins for commenting on the manuscript, Manolo Arias Silva and his family and staff of Perúflora for logistic support and hospitality.

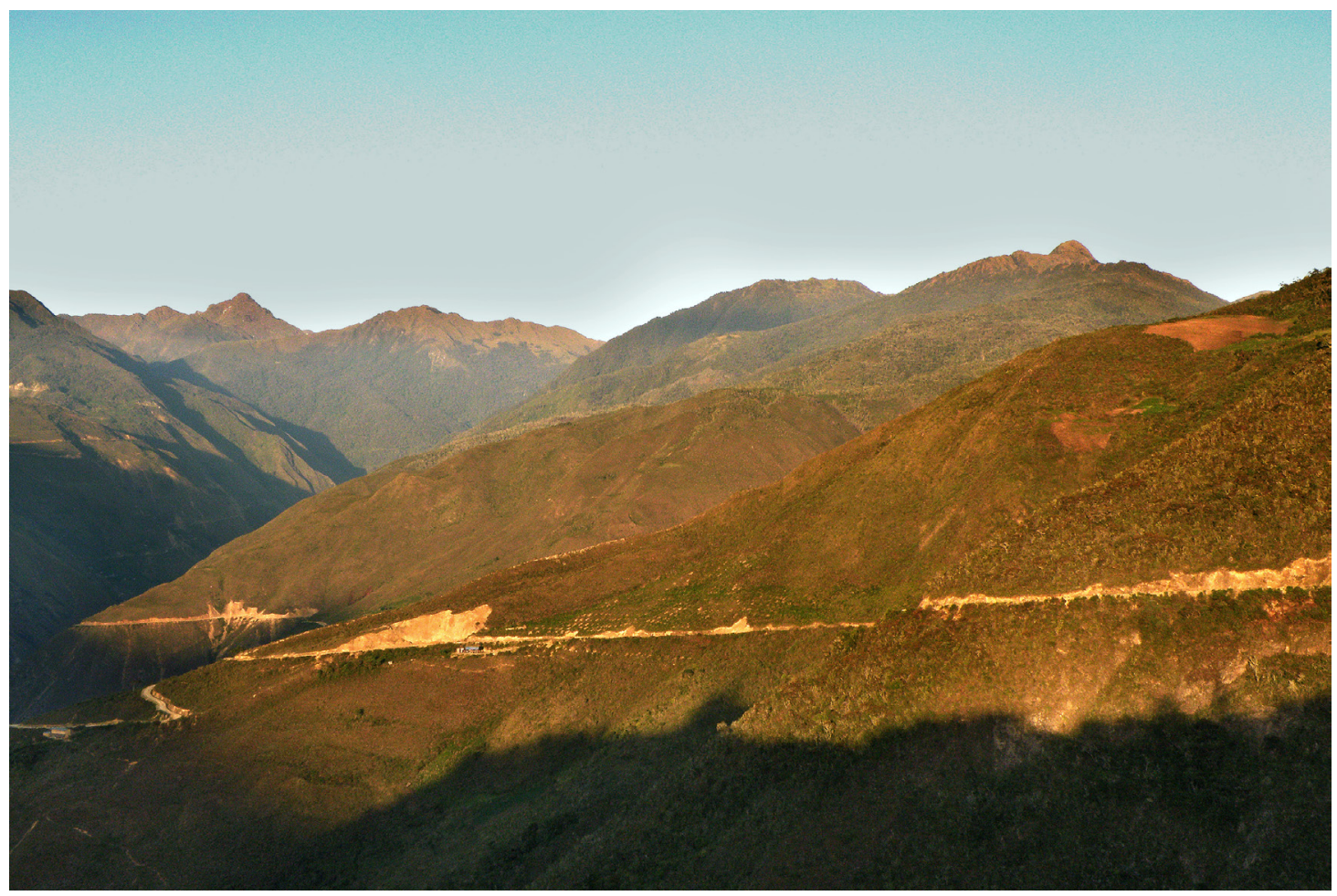

Figure 5. The deforested habitat of Masdevallia tatianae Dalström \& Ruíz-Pérez, in Huanuco, Peru. Photograph by S. Dalström. 


\section{LITERATURE CITED}

Abele, C., Rudolph, B., Thiede, J. \& Rohwer, J. G. (2005). Phylogeny of the genus Masdevallia Ruíz \& Pav., based on morphological and molecular data. Proceedings of the 18th World Orchid Conference, Dijon, France, 111-115.

Dalström, S. \& Ruíz Pérez, S. (2014). Three new Masdevallia species (Orchidaceae: Pleurothallidinae) from Peru. Lankesteriana, 13(3), 251-258. Doi: http:// dx.doi.org/10.15517/lank.v13i3.14362

Luer, C. A. (1986). Icones Pleurothallidinarum 2, Systematics of Masdevallia (Orchidaceae). Monographs in systematic botany from the Missouri Botanical Garden 16. Missouri Botanical Garden Press.

Luer, C. A. (2000a). Icones Pleurothallidinarum 19. Systematics of Masdevallia part one. Monographs in systematic botany from the Missouri Botanical Garden, 77, 1-264. Missouri Botanical Garden Press. . (2000b). Icones Pleurothallidinarum 21. Systematics of Masdevallia part two. Monographs in systematic botany from the Missouri Botanical Garden, 82, 265-518. Missouri Botanical Garden Press.
(2001). Icones Pleurothallidinarum 22. Systematics of Masdevallia part three. Monographs in systematic botany from the Missouri Botanical Garden, 86, 510-780. Missouri Botanical Garden Press.

. (2002). Icones Pleurothallidinarum 23.

Systematics of Masdevallia part four. Monographs in systematic botany from the Missouri Botanical Garden, 87, 781-1047. Missouri Botanical Garden Press.

. (2003). Icones Pleurothallidinarum 25. Systematics of Masdevallia part five. Monographs in systematic botany from the Missouri Botanical Garden, 91, 1049-1293. Missouri Botanical Garden Press.

(2006). Icones Pleurothallidinarum 28, A reconsideration of Masdevallia, Systematics of Specklinia and vegetatively similar taxa (Orchidaceae). Monographs in systematic botany from the Missouri Botanical Garden, 105, 1-6. Missouri Botanical Garden Press.

Pridgeon, A. M. \& Chase, M. W. (2001). A phylogenetic reclassification of Pleurothallidinae. Lindleyana, 16(4), 235-271. 
